\title{
The Critical Exposure of Lesotho's Labor Law Effectiveness: Industrial Relations' Calamity of Textile Industry Workers in Lesotho
}

\author{
Moses M. M. Daemane \\ National University of Lesotho, Roma Campus, Lesotho \\ mosesdaemane@gmail.com
}

\begin{abstract}
This article provides insights on tribulations of Lesotho textile industry workers and effectiveness-extent of national labor law in shielding labor rights. It is a qualitative and quantitative research premised on textile industrial areas of Thetsane and Railway Station area in Maseru city, Labor offices and workers/trade unions. It illuminates the prescriptions of the Labor Law in Lesotho pertaining to the textile industries and inquires whether such Labor Law is not nominally applied in protecting textile factory workers' rights. It examines workers' organizational capacity and bargaining, role of workers' trade unions in addressing workers' concerns and maintenance of labor law. Elucidation embraces efficacy of legal resolutions procedure followed whenever there are disputes between workers and management, reported by either the individual workers or workers' trade unions/TUs. Outlook of the workers to examine their content concerning services rendered to them by labor offices forms part of this researched debated in-depth interviews. Dictates of the Law towards lowly esteemed workers and the extent to which their rights as workers in Lesotho are protected by the government mold chief innards. Findings reflect on benefits ought to be derived from this industrial sector but which are inconspicuous, thereby ensuing in destitution of workers whose majority are women with significant dependency ratios. Labor downsizing, layoffs, unfair dismissals, salary cuts and/or delayed labor earnings, toiling beyond normal working hours, chronic lung diseases from inhaled harmful chemicals, labor devalourization, vulnerability and others constitute quandary of Lesotho textile industry workers. The research question is, then, how far does the law work for them through pro-active and reactive (remedial) strategies for their emancipation, protection and recompense/welfare?
\end{abstract}

Keywords: Exposure, labor law, industrial relations, textile industry

\section{Introduction}

This is a face-to-face in-depth interviews research study on the Lesotho's Labour Law effectiveness in governing industrial relations of the textile industry local workers. Industrial relations in Africa have proved to be an issue among the economists, political scientists, sociologists, other scholars and many organizations affianced. The emphasis is that systems of labor relations in industrial areas are almost entirely required to be governed by law ${ }^{1}$. How effective is the governing of such a law is this paper's enquiry in Lesotho. The gist is thus the degree of Lesotho's labor law effectiveness in terms of its enforcement and protection over the masses of Lesotho textile industry workers. These are the workers generally known and observably characterized by severe exploitation, job insecurity, subjection to hazardous working conditions comprising among others of harmful chemicals, unsafe workplace and work practices, remarkable legal illiteracy and as thus vulnerability and health hazard, whose majority are women with large dependency ratios (Lesotho's Labour Law Effectiveness Interviews, January, 2014).

One's assumption in this study is that laborers' organizational capacity and effective participation not only at the 'floor management level' but inclusive of the policy formulation level are probably defunct in Lesotho, though textile industry is said to be the fastest growing sector largely possessed by infesting foreigners with a margin of more than $95 \%$. This has so far ensured capital flight, lack of multiplier effect, higher Gross Domestic Product/GDP than Gross National Product/GNP, which is skewed growth aggravating poverty index, decreasing income per capita and worsening quality life aggregately. The escalating gini-coefficient avers national unemployment rate of $45 \%$ but $80 \%$ in the rural areas, staggering poverty and inequity. The research paper further assumes that this massive foreign owned exploitative employment creation is far from quality life enhancement except a destitution process/cyclic poverty and worsened vulnerability even in the face of existing labor laws. That is working conditions are

1. Damachi (1979), essentially this has been an international issue since ILO establishment. 
not favorable though legal standards are set for the industries and as thus negligence of Labor Law in Lesotho when it comes to textile industries' workers does prevail.

Justifiably, effective application of labor law in Lesotho textile industry need not leave much to be desired since this is said to be the fastest growing employment sector of the country, employing more than 40,000 workers in 2003 and 70, 000 in 2012. ${ }^{2}$ In this era where industrial relations have shifted to human resource management (HRM), it is indeed rational to detect the effectiveness of Lesotho labor law at any level on these textile industry workers, also considering their above-defined characteristics. Law is not meant to be a paper issue only. Furthermore, the industrial sector is vitally important to the economy of Lesotho and contributes significantly to the country's exports and manufacturing sector for global distribution system (GDS). Lesotho's export through this sector, to the United States has been US $\$ 140.3$ millions in 2000 and increased to US\$215.3 millions in 2001. The number of workers also grows every year (World Socialist Website, 27 October, 2013).

Industrial sector has also brought economic changes to Lesotho. The country as was the British protectorate from 1860s until 1965, women were not allowed to access bank loans or enjoy income independence from their husbands who were mostly migrant laborers as cheap labor in South African mines. This has relatively changed due to these textile factories, which employ women exclusively, making them thousands of female family breadwinners. Many authors state that women's labor in many societies is undervalued monetarily and otherwise. Could this be true as well for women working as textile industry workers in Lesotho especially within the existent labor law and their contracts? Labor law is generally known as a collection of case notes and references relating to employment and labor. It is the material related to employment contract and employment protection in notes of cases on wrongful dismissal, equitable remedies against employees, statutory definition of dismissal, redundancy and unfair dismissal. The issue is to what extent does effective administration of this labor law that then becomes industrial relations prevail in Lesotho? It is also generally known that industrial relations are the dealings or relations of industrial concerns with its employees, the public and so on, the administration of such relations, especially to maintain goodwill for an industrial concern (www.factmonster.com, 2013). Effectiveness in relation to labor law refers to the situation in which all labor institutions are satisfying the provisions of the labor law; that is the employees' rights are respected and labor standards are observed.

This question of labor law effectiveness is of paramount importance because Lesotho like other countries has entered into International Labor agreement and acquired membership of the International Labor Organization (ILO). There are some conventions guiding members of this organization and such regulations too, apply to Lesotho as the member state. One of the objectives of ILO is the promotion of labor justice. It urges workers to form organizations that shall be free from interference by the public authorities. It also condemns forced labor against workers or exploitation. It is strongly arguing against unfair unequal treatment of men and women in the work place. It also gives workers a right to go into strike if they feel that they are being unfairly treated. Workers have the right to work in the conducive environment (Tikriti, 1982). Sadly, in Lesotho, the police claiming such strikes to be unlawful shot to death women workers in textile industries during their strikes in demand for a living wage, in a number of strikes. Women workers in these industries also report that during such strikes their leaders just disappear and are found shot dead the next day by the roadside (Lesotho's Labour Law Effectiveness Interviews, January, 2014).

\section{Methodology}

Since every textile factory worker was found to be cooperative in readily exposing their calamity through information provision, formal in-depth interviews conducting a questionnaire adopted simple random sampling so as to enhance representation and prevent bias. Ten men and forty women working in Thetsane industrial area and Railway station area textile industries served as respondents. Five labor officers and five trade unions' officials were also interviewed. The study used open-ended and closed ended questions to maximize data collection. Particular members from the workers' trade unions were interviewed as well to have a view of the trade unions' role. Desk study of the labor documents and reported cases by the respective offices of labor department and trade unions formed secondary data. Data analysis involved descriptive statistics, other various quantitative methods and qualitative ones.

\footnotetext{
${ }^{2}$ LNDC Investors Guide.htm, $10 \backslash 09$ \2013, GOL plans to increase job opportunities to more than 80,000 soon.
} 
Finding factory workers who have very short breaks of at most thirty minutes for lunch and only fifteen minutes for some rest from seven o' clock in the morning to seven o' clock in the evening made interviews to have many breaks on an individual respondent. Shifts that went to work at seven o' clock in the evening knocking off in the morning at the same hour were scarcely available for interviews. They had to be interviewed at their small rented inadequately equipped single rooms used for every living purpose. Observation and interviews used confirmed that textile factory workers are asset poor, lack livelihoods and/or extra sources of income not to talk of any financial contributions or benefits by their employers (Lesotho's Labour Law Effectiveness Interviews, January, 2014). Visiting textile factories for observation was denied by every factory approached for this research. The first problem was the English language to non-English speaking foreign investors who can hardly make one correct English sentence. Participant observation could be effective but court cases, other documents and workers' reports were also enough.

\section{General Situation With Regard To Labor Law in Africa, Particularly Lesotho and Its Textile Industry Overview}

Lesotho has its own regulations regarding labor for both the public and the private sector. The provision is for both the employers and employees. Regardless of the provisions of these legislations, there are still some complaints within the worker-job field that apply to industries in Africa as a whole. As Panford (1994), has put forward, there is still unfair dismissal of employees, unfair wages, in conducive working environment and repression of workers' trade unions. In the case of the textile industries in Lesotho, there is a big problem. The report from Clean Clothes Campaign (2001) indicates workers to be still illegally dismissed from their jobs. They are still exploited and in some cases forced into unpaid overtime. There is still repression of trade unions' rights, violation of health and safety standards such that emergency exits are sometimes locked with padlocks. Factories have no temperature regulations therefore; they are very hot in summer and very cold in winter. There is hardly any safety equipment in the factories, wherever existent employers rarely condone such equipment use, except when they are sure of the usually communicated visits of labor inspection officers. When such inspection is to be done, adequate light in the factories will be ensured for that day only. Workers wish labor inspectors could come every day especially during winter because heaters only work when they come for inspection (Kahn-Freund, 1972, Lesotho's Labour Law Effectiveness Interviews, January, 2014).

The major task of labor law in the external market is to assist in training programs in order to enhance vocational skills, offer public employment, exchange services to help workers obtain jobs while strictly regulating private intermediary business and to provide benefits to workers who have lost their jobs to mitigate hardship during their unemployment. Interviews with the Lesotho textile factory workers have found naught on these aspects. This is to confirm that labor law in Lesotho is not effective and indeed, here, factory workers are a hand to mouth type of living category of people (Lesotho's Labour Law Effectiveness Interviews, January, 2014). The employee and the employer have to sign a contract that states conditions of employment, but in many cases workers are greatly disadvantaged by the labor surplus which has been a dominant feature of the labor market and as such most times there are no contracts signed by Lesotho factory workers. They therefore easily get dismissed or remain mistreated and disadvantaged in this employment sector. They do not know or have any benefits to bargain for or claim on the basis of any negotiated formal signed contracts. To safeguard the workers positions in the labor market transaction, standards for the terms and conditions of employment have to be established through legislation while the collective bargaining power of workers has to be ensured. The significant issues under regulation are wages, working time, dismissal, safety, health and compensation for work related injuries and diseases. With regard to bargaining power, the law guarantees the worker the right to organize and act collectively and set-up mechanism for resolving disputes involving workers' collective demands and actions. In the absence of formal contracts, workers remain at the 'goodness' of their factory employers who are not necessarily bound by any legal agreements. The main aim of labor law is to be a countervailing force to counteract the inequality of bargaining power, which is inherent in the employment relationship. Mere absence of contracts invalidates functionality of this aim in Lesotho (Lesotho's Labour Law Effectiveness Interviews, January, 2014).

Women workers in these factories substantially suffer from one form of illness due to severe either cold or inhaled chemicals at workplace. Pregnant women report to be badly treated, in some cases they are made to stand for a long time, their wages are also deducted when they fail to come to work due to pregnancy complications. Workers are still underpaid in these industries (also see 
www.globalpolicynetwork.org, 2005). The standard minimum wage for each employee in Lesotho is eight hundred and eighty Maloti per month (M880.00 equivalent to \$US85) but in most factories workers are still paid six hundred Maloti (M600.00 equivalent to \$US60) per month. All these problems are incidental within the existence of Labor Law regulating these industries (Lesotho's Labour Law Effectiveness Interviews, January, 2014). There has been shortage of employment opportunities in Lesotho for a long time. Directly after gaining independence from the United Kingdom, which is in 1965, Lesotho National Development Corporation (LNDC) was established as a government entity to plan industrial work opportunities and form incentives for promoting industrial investment in the country. This mainly followed foreign investment attraction strategy known of capital flight and lack of multiplier effect on the local economy. Incentives put to achieve this included tax free periods to foreign investors, subsidized or lowered costs of input services like water and electrical supply, serviced industrial sites and infrastructure, too low minimum wage rates far below acceptable consumer index, poverty line and in general below a living wage, resulting in labor exploitation, credit or loans to foreigners who are to own factories basically managed by natives. Such credit often misses the natives that are more qualified in business skills than foreign locally credited entrepreneurs or even ends up in the hands of never a targeted group for poverty alleviation, the ruling elites. The aim was to raise the level of employment in the country and thereby alleviate poverty. The government recognized that good industrial relations form the right strategy for attracting the new investments and basis for high productivity needed to boost employment and living standards. The actual practice, in view of that has been a scenario where in Lesotho the sky is the limit for profit maximization by foreign (at times locally credited) investors at the expense of mainly women factory labor (Clean Clothes Campaign, 14 July, 2001). LNDC worked with 40 companies that were investing in Lesotho from 1973 to 1999. It is reported that in the 1970s to 1980s companies investing in Lesotho were producing products including umbrellas, bricks, auto parts, pharmaceuticals and garments. Most of these companies were from the Republic of South Africa/RSA. Around 1990s, Lesotho's industrial investment shifted mainly to garments industry whereby 15 of the 22 investing companies were garments industries, which keep on expanding their factories (Clean Clothes Campaign, 2001).

Some More Aspects and Provisions of the Lesotho Labor Law in Perspective: Lesotho labor law in practice requires extensive consultations between employees and employers. This is to ensure that industrial action may only be taken after extensive consultations in resolving worker management disputes. The trade unions also exist to facilitate communication between workers and management. The most famous of these trade unions is Lesotho Clothing and Allied Workers' Union (LECAWU). There are laws that regulate the industries. Furthermore, Lesotho Labor Law has been consolidated into a new labor Code gazette as order no 24 of 1992. This order regulates both the employers and employees respectively on proper procedures in all aspects of industrial relations (LNDC-Investors Guide, 2004). This Code, during the military governance era (1986-1993), was made in such a way that amendment, codification and consolidation of the laws relating to employment and matters incidental thereto be made as necessary. It was thus enacted by the Military Council ('representative of all Lesotho community sectors') which is equivalent to the Parliament today. As the Labor code order it was expected to operate every time as the Minister may appoint by the notice in the Gazette. It was supposed to apply to any employment both in the public and private sector and served as an apprentice in labor issues. The Minister, nonetheless, could not make any exemptions contrary to international Labor Convention, which Lesotho has adopted. The order was first amended in 1994, and consolidated as arrangements of rules; Labor Court Rules of 1994, it was then called Labor Code order 1994. Bredan Peter Cullinan who was the Chief Justice at that time, and the president of Labor Court were the ones who made these rules. The second amendment was made in 2000 as Labor Code (Amendment) Act 2000. This time it was enacted by the (1993) democratically elected Parliament of Lesotho. The Labor Code provides the tripartite bodies in which government and workers are represented. This Tripartite Boards include; the National Advisory Committee on labor, Wages Advisory Board and the National Council on Occupational Safety and Health.

Section 91 (1) of the Labor Code Order, 1992 provides for the workers health, safety and welfare at work. It gives employers an obligation to practically ensure safety, health and welfare but this is nominally applied. Safety, health and welfare are not guaranteed in textile factories of Lesotho. Subsection (2) gives the employer the duty to provide and maintain the working environment for his $\backslash$ her employees and this should be reasonably practicable but it is naught according to factory workers' reporting. Legal requirement includes the environment that is safe, clean and without risk to health and that is adequate as regards sanity facilities and arrangement for their welfare at work. Much is still left desirable according to textile factory workers on this standard or legal aspect. Toilets are reported to be out of order and 
unclean most of the time (Lesotho's Labour Law Effectiveness Interviews, January, 2014). Section 97 (1) provides that registered health and safety officers should be appointed for supervision regarding compliance with the provisions of this part and to promote the safe conduct of the work. Textile industry workers regard these officers as tourists, non-effective people in their visits who never interview workers about the real situation and believe everything the non-native exploitative employer tells them (Lesotho's Labour Law Effectiveness Interviews, January, 2014).

In relation to the working hours, the Lesotho Labor Code Order 1992 stipulates that every employee shall be allowed a weekly rest period of at least 24 continuous hours which shall include Sunday as the day of rest. The reality is that should one take such a rest, it is at the expense or loss of his or her daily wage. This ends up compelling workers to work underpaid overtimes. Subsection (2) provides that employee must be paid if requested to work overtime and this should be double her $\backslash$ his wage rate for an ordinary day. Textile industries do not abide by this standard (Lesotho's Labour Law Effectiveness Interviews, January, 2014). Apart from that, Section 118 has provision for the ordinary hours of work and overtime. Labor Law in Lesotho requests that employees should work for at least not more than 45 hours per week, which is ordinarily nine hours on a five-day week and for the employees who work a six-day week it should be eight hours of working hours and five hours on a day. Subsection (2) proceeds to state that employees should not work for continuous five hours without a break of not less than an hour, during which time she $\backslash$ he shall not be required to perform any task. Textile industry workers are only allowed to take a break of at most thirty minutes. Apart from that, Subsection (3) provides that if the nature of work is to work continuously, where the employee is requested to work overtime of up to eleven hours in one week, the employer shall pay such employee for the overtime at a rate not less than one and one quarter times his or her normal working rate. This entitlement, the law requires that it shall be without prejudice to an employee's entitlement under Subsection (2). Overtimes are mostly underpaid and do not follow this set legal standard (Lesotho's Labour Law Effectiveness Interviews, January, 2014).

Section (121) is the law pertaining to public holidays; it provides that every employee is entitled to a dayoff with pay on every public holiday declared in accordance with the provision of the Public Holidays Act, 1967. If such employee works, Subsection (20) requests that he/she shall be paid double the normal wage rate for an ordinary working day, or he/she shall be paid the normal wage rate for an ordinary working day, or he/she shall agree with an employer that he/she be paid normal daily wage. This is not maintained; instead 'casual' workers are sought and they remain 'casual' for many years from one factory to another. This in itself weakens and deprives them of permanent employment benefits and sustainable effective organizational capacity while enabling factories' profit maximization and labor disempowerment (Lesotho's Labour Law Effectiveness Interviews, January, 2014). The Lesotho Labor Code also protects workers' rights in relation to their sick leave. Code order No. 123 provides that workers be given the sick leave only after the first six months of employment with the same employer, before then, the sick leave may be unpaid. This leave counts up to 12 days at the second six months. After 12 months, employee is entitled to full pay sick leave of up to 12 days, then sick leave of half pay for up to 24 days in each period of 12 months with the same employer. In all these cases, an employee has to produce sick-leave certificate signed by a registered medical practitioner or a person in charge of the dispensary. This is provided in Subsection (5) of Section 123. Textile factory workers report to be highly mistreated on this standard because there are no sick-leaves; one's daily wage gets cut per day and is treated to be absent. A few days absent from work due to illness qualify for immediate dismissal. This is said to be a 'normal' trend here. Workers lack knowledge about their rights and right procedures that protect them (Lesotho's Labour Law Effectiveness Interviews, January, 2014).

Apart from this general sick leave, the Lesotho Labour Law also provides for the protection of female employees; that they produce to their employer written certificate signed by a medical officer including a registered nurse or midwife, certifying that the employee's confinement will take place within six weeks from the date of the certificate. As such Section 136 (1) provides that any dismissal from work of such employee during her maternity leave is an unfair dismissal. They usually get displaced and replaced permanently anyway. Moreover, Subsection (2) requires that in no way should a pregnant woman who has made an official notice of her pregnancy and confinement be given a notice of dismissal or termination of her contract during the period of her absence from work. This legal standard lacks enforcement because there is always this surplus labour immediately absorbed to displace and replace the pregnant one as a 'casual' labourer for no definite period. They remain (casual) so because they are cheaper to pay, are not regarded as permanent employees entitled to other work benefits and can be dismissed at any time. Most of the textile factories therefore have more than $50 \%$ of their workers as 
casual labourers. These are basically undeclared long time employees without benefits, lacking organizational capacity or trade union membership and bargaining power. Casuals may be told not to come to work tomorrow at any time; they are so job insecure and avoid taking bargaining positions (Lesotho's Labour Law Effectiveness Interviews, January, 2014). This brings one to then reflecting on the expected international labour standards through International Labour Organization/ILO.

International Labour Organisation (ILO) and Labour Standards: The International Labour Organisation (ILO) is the specialised United Nations agency whose aim is to promote social justice and internationally recognised human labour rights; the establishment of ILO is dated back to 1919. ILO has become the foundation for international labour standards in the form of Conventions and Recommendations. It sets the minimum standards of labour rights, among others; freedom of association, the right to organisation, collective bargaining, abolition of forced labour and equality of opportunity and treatment. ILO also sets minimum standards that regulate the entire work conditions. Apart from that, it offers to its member states the technical assistance basically on the fields of vocational training and vocational rehabilitation; employment policy; labour administration; labour law and industrial relations; working conditions; management development; cooperatives; social security; labour statistics and occupational health and safety (Hugh, 1985 and www.ilo.org.2005). ILO has recognised that as a result of globalisation, workers' rights have been to a larger extent, compromised in the field of international competition; so the aim of ILO in the field of labour has been to help prevent international competition from taking place to the disadvantage of the workers. The driving force behind the idea of international labour law, as it has been outlined was the notion of social justice. In the field of labour, the humanitarian concern originally appeared in the face of great hardships imposed on the workers by industrialisation (www.ilo.org.2005).

The International labour standards used by ILO are argued to serve as a general guide and as a source of inspiration to governments by virtue of their authority as texts adopted by an assembly composed of representatives of governments, employers and workers of nearly all countries of the world. Consequently, they may provide a basis for the claims of workers and guide the policy of employers. Officers in charge of social policies in various countries have thus often highlighted this role of international labour law. The ILO sources of International Labour Law can be found in the ILO constitution and in its numerous Conventions and Recommendations. These Recommendations do not create an obligation but rather provide guidelines for action. Eight Core Conventions have been adopted in the ILO and are expected to be observed by all member states, Lesotho inclusive. The first one is Convention No. 87 of 1948. It provides for the 'Freedom of Association and the Right to Organise'. It establishes a right of all workers and employers to organise themselves into unions and organisations. Each employer or worker is given a chance to join organisations of his $\backslash$ her own choice without any interference by the authority. These organisations on the other hand are guaranteed free functioning without interference by the public authority (Hugh, 1985 and www.ilo.org.2005).

The other core convention is the convention No. 98 of 1949, 'the right to Organise and Collective Bargaining'. It provides for protection against anti-unionism, discrimination and employer's interference. Convention No. 29 of 1930 prohibits forced or compulsory labour in all its forms with certain exemptions for military services, properly supervised convict labour and emergencies such as wars and national disaster. The other one is the Convention No. 105 of 1957 which prohibits the use of any form of forced or compulsory labour as a means of political coercion of education, punishment for the expression of political or ideological views, work force mobilisation and labour discipline, punishment for participation in strikes or discrimination. Convention No. 111 of 1988 calls for national policy to eliminate discrimination on the basis of access to employment and training and working conditions or grounds of colour, sex, religion, political option, national extraction or social origin and to promote equality of opportunity and treatment (www.ilo.org.2005). One other core convention is Convention No.100 of 1951 which calls for equal pay for both men and women for the work of equal value. The last one is Convention No. 138 of 1973 which aims at the abolition of child labour, stipulating that the minimum age for admission to employment shall not be less than the age of completion of compulsory schooling and in any case not less than that of 15 years, (14 for the developing countries). It also stipulates minimum age for admission to hazardous work. Besides the eight Core Conventions, there is also the other important one relating to occupational health and safety. It addresses steps that should be taken to prevent accidents and injury to health (www.ilo.org.2005). This research study confirms beyond reasonable doubt that these ILO's core conventions of which Lesotho has also signed for are not observed in her textile industry sector (Lesotho's Labour Law Effectiveness Interviews, January, 2014). 
Assessing the Role of Trade Unions in the Context of Lesotho versus Labour Law Practices: Labour standards are easy to maintain where trade unions exist and function effectively. Only that most of them in Lesotho rely on subscriptions of underpaid workers whose majority are strategically left as casual workers permanently and thus to a greater extent lack organizational capacity. Trade unions in Lesotho do not strive to be shareholders in the employment sector and yet still vainly hope to enjoy membership loyalty. Since they lack functional vision of being at par with employers by being employers themselves, either through negotiating for themselves or their membership to become shareholders in the production/employment sector, they thus lack effective capacity, resources, political and bargaining power to influence formulation of labour laws practically serving their interests and equitable application of such law. Hyman (1987) regards trade unions as the agencies and medium of power whose aim is to redress the imbalances of power in the work place. Trade unions represent continuous association of wage earners for the purpose of maintaining or improving the conditions of their working lives. They work towards enhancing the material conditions of their workers and to establish a joint rule-making system protecting their members from arbitrary managerial actions and allow them to participate in the organization for which they work and to express the aspiration and political ideologies of their members. Trade union members when asked whether this is the reality in Lesotho, they complained that managerial staff of trade unions is the only ones whose lives improve from membership subscriptions and very high commissions from services offered by these trade unions to their penniless members. Trade union leadership is blamed for joining government delegation in attracting foreign investors at the detriment of workers by condoning negotiations that do not embrace their interests of good living salaries, safety and health at workplace (Lesotho's Labour Law Effectiveness Interviews, January, 2014).

Trade unions should put more emphasis on the health and safety of workers and pursue other issues such as wage, working time and collective bargaining. They should always remind employers and workers to pay attention to safety and to guard them against false security that is they should clear off the notion of 'it will never happen to me' among the workers and employers. Global unions have discovered the fact that over two million women and men die each year from unsustainable forms of work and 160 million more become the victims of work related diseases, (www.icftu.org, 2005). They also recognize the conditions fostered by globalization which induce the replacement of safe and healthy workplaces in one part of the world by more dangerous working environment in others. Union membership in Lesotho feels that it would be best that labour officials also come from trade unions as workplace inspectors and not only from the government regarded to be corrupted by the employers so that they are lenient with them (Lesotho's Labour Law Effectiveness Interviews, January, 2014). By adopting social and employment linkages to economic and environment planning for the next decade, the World Summit on Sustainable Development (WSSD) has created new opportunities for trade unions to better introduce poverty, equity and work place issues within the national plans to address the world's current destructive production and consumption patterns. In the context of Lesotho, trade unions feel that they are left out in poverty reduction strategies by the country's governments (Lesotho's Labour Law Effectiveness Interviews, January, 2014).

Trade unions are taking a leading role to better integrate sustainable development with occupational health and safety for workers and to strengthen the basis for promoting forms of decent work and the well being for workers and communities, (www.icftu.org.2005). They facilitate most of collective bargaining that takes place quietly with quick agreements reached by the union and the employer. Trade unions also facilitate disputes settling between employees and employers. They are stewards for workers participation in decision and policy making. Trade unions in Lesotho find themselves inhibited in effectively playing this role because incentives put by LNDC and the government do not promote equity and employees' empowerment. The government regards unions as destroyers of its efforts to generate employment opportunities because they incite strikes for better pay. It is as if the main interest of the government is to have numbers employed while unions' main interest is to have workers well paid, not exploited (Lesotho's Labour Law Effectiveness Interviews, January, 2014).

Unionism involves negotiations whereby unions' representatives discuss with management issues which affect people working with an organization. The union finds out members' views and communicates these views to management. This fosters collective bargaining. In many work places there is a formal agreement between the union and the company stating that the union has the right to negotiate with the employer. In these organizations unions are said to be recognized for collective bargaining purposes. Pay working hours and changes to working practices are the sort of issues negotiated. People who work in 
organizations where unions are recognized are usually better paid and are likely to be made more redundant than people who work in organizations where unions are not recognized. The main constraint to Lesotho trade unions with regard to this role is that minimum wage is already very low and most investors keep operating only if salaries are kept low as part of low input costs. There are factories reported to have closed because workers' unions pressed for better pay but which continued and/or immediately opened new factories in the neighbouring country where salaries are normally very high. Badly too low minimum wage is said to be condoned by the government as an incentive to keep and attract more investors who only want to maximize profits through cheap labour and when such is challenged by workers' unions these investors leave to nearby countries but with higher minimum wage rates. There are also cases whereby textile factory owners defended themselves for bad pay behind low minimum wage set by the government, too minimal to be a living wage considering inflation and normal living standards. Lesotho trade unions still have a lot to do concerning this role, not unless they directly pressurize and negotiate with the law making structures (Lesotho's Labour Law Effectiveness Interviews, January, 2014).

The unions also represent individual members when they have a problem at work especially when an employee feels that he/she is being unfairly treated. He or she can ask the union representatives to sort out the difficulty with the managers or employer. If the problem cannot be resolved, the matter may go to the industrial tribunal (IT). The tribunal may make employment laws and see to it that they are properly adhered to by employees and employers. ITs are made up of people outside of work place who listen to the employers and employees point of views and then make some judgement about the case. Employees can ask their union to represent them at IT. Most of cases that go to the IT are about pay, unfair dismissal, redundancy or discrimination at work. Unions also offer their members legal services and representation. Normally this is to help people get financial compensation with work related injuries or to assist people who have to take their employer to court. Unions also have a wealth of information which is useful to people at work. They can advice on a range of issues like how much holiday a worker is entitled to each year; how much pay a worker gets if one goes on maternity leave and how a worker can obtain training at workplace. Trade unions in Lesotho normally represent employees in ITs including Lesotho labour court and Directorate of Dispute Prevention and Resolution (DDPR) recently enacted through the parliament, except that such representation claims unreasonable large shares from employees' recompense (Lesotho's Labour Law Effectiveness Interviews, January, 2014).

Most of the trade unions run training courses for their members on employment rights, health and safety and other related issues. Some help their members who have left school with little education by offering courses on basic skills and at times courses leading to professional qualifications. Trade union members in Lesotho state that as for this role, their unions perform very poorly. They are blamed for lack of capacity, skills, information, mismanagement and abuse of limited resources (Lesotho's Labour Law Effectiveness Interviews, January, 2014). The 2003 statistics of the total workforce in Lesotho shows that the workforce of textile industries was 54,000. For the unions to be powerful, they should have the majority of the workers as their members, at least more than $50 \%$ of the workers. The total membership of LECAWU is estimated at around 900 to 1000 people while FAWU is having 21,827 members and Lentsoe La Sechaba has less than five thousands membership. This small membership constrains power of unionism and labour law effectiveness. These unions at times provide financial loans to their members. Trade unions in Lesotho are not yet share holders in investing and unless and until they match employers they will remain ineffective and powerless for a long time (Lesotho's Labour Law Effectiveness Interviews, January, 2014).

Some more Tribulations of Textile Industry Workers in Lesotho and Elsewhere: The bad working conditions and environment in the textile industries are not the work problems found in Lesotho only, but also in other countries, both in the developing and developed countries. Many reports have highlighted some of the problems that are experienced by people working in the textile industries. The report from Vietnamese newspaper, Lao Dong ("Labour"), says that at the beginning of 2000, the Ministry of industry predicted a very promising future for the textile-garment industry. That production had to double as well as the value of the products. In 2000, the domestic demand for cloth and silk was estimated at 1, 10 million metres. As estimated by the General Textile Garment Company, export turnover was estimated to reach US $\$ 11,000.000$ by the year 2010. The textile-garment industry therefore promised to develop quickly in Vietnam but the health of over 500,000 workers is reported to stand in inverse proportion to this cheerful assessment. They are working in conditions and environment that adversely affect the most valuable asset, health. The working environment of the textile-garment workers 
is reported to be less hard, though when compared to other industries it is reported to be too labour intensive with a very high pace of work for production of tonnes of garments within the shortest period ever. Such labour intensification is said to be too stressful on the body and creates many health complications to many workers within a very short period. As a result workers in these textile industries come forth in the ranking of toil-levels. Lesotho textile industry workers are not an exception to this tragedy. Newly breastfeeding women have complained of fatigue that resulted in some of them having suffocated their sulking babies to death due to fatigue that made them fall into deep sleep with breasts out blocking babies' nostrils. Exhaustion resulting from working from 7:00 a.m. to 7:00 p.m. with 30 minutes break for lunch, 15 minutes break for rest at 10 or 11 a.m. and 4:00 p.m. is but exploitative toiling (Lesotho's Labour Law Effectiveness Interviews, January, 2014, also see Panford, 1994).

The demographic aspects of textile industries' labourers in Lesotho confirm that this is fourth ranking job in toil-level as analysis provides that there are no employees over 40 years of age here. Age group 15-20 constitutes $8 \%, 21-2526 \%, 25-3034 \%, 31-3520 \%$ and $36-40$ constitutes $12 \%$. As thus most of the textile industry workers are at the age of 25-30, 21-25 and 31-35, respectively. Many do not see themselves working beyond the age of 39 or 40 here because the job is too labour intensive, stressful, tiresome and causing many ailments on their bodies. One other interesting demographic aspect of these labourers is that women constitute $82 \%$ of the total labour force employed in these industries. Could it be that underpayments are due to widespread undervaluing of women's economic activities or is it just an issue of a gender blind policy? One would say yes to both. This discriminatory trend includes practices such as just expelling women with big breasts or who are fat or simply refusing them employment openly on grounds that they are lazy and cannot be fast enough in doing this job, they are too fat. The young age groups working here have their marital status as follows; $38 \%$ are married, $34 \%$ are single, $18 \%$ are separated, while $10 \%$ are widowed. The percentage of the single is found to be very significant at workplace, here, the tedious nature of the job may only be endured by the young ones. This indicates toiling and exploitation (Lesotho's Labour Law Effectiveness Interviews, January, 2014).

The Japanese have also faced the same problems. Working in the industries has also been the problem for the young ladies in Japan. One worker from the textile industry reported that due to her age (as she was very young); she was made to clean up the waste pieces of thread. She said that she used to do that type of work for twelve hours in a day, from 6:00 a.m. to 6:00 p.m. and they were allowed only 30 minutes break for lunch and 15 minutes breaks at 9:00 a.m. and 3:00 p.m. Injury during work was not taken as a serious matter, instead, it was taken as a 'substantial loss' for the company. Workers had to take care of their injuries; even going for medication was the responsibility of the injured individual. So far in Lesotho, as well, there is no textile industry that takes responsibility on work injuries. First aid kits are always out of any medical materials while in most of the factories they are not there at all. Tuberculosis is very common among Lesotho textile industry workers, this was same for Japan. Workers are made to work and live in damp, poorly ventilated spaces and this is a very contagious or infectious disease as it may be airborne (Lesotho's Labour Law Effectiveness Interviews, January, 2014, see Sako and Sato, 1997).

Besides the Japanese, the workers in the textile industries in Pakistan are also having the related problems. The larger proportion of citizens living in the cities are working in the industries either being garments, handicrafts, cotton picking or other related home based industries. The labour laws are said to be very good in theory as is the case in Lesotho. There is no implementation of labour law and industrial tribunals are very lengthy in this country. The country report of Pakistan reported that in some cases workers who had been unfairly dismissed could spend five to ten years in the basic labour court, while other workers spend their entire lives in Appeal Court, High court and the Supreme Court seeking reinstatement. According to the Pakistan's Factory Act, the work places are not 'up to the mark'. The workers become permanently disabled by the accidents that often occur on the slippery floors due to lack of medical attention (See Tikriti, 1982).

Due to the ineffective labour laws, there is no proper protection of trade unionists, trade union officials or active members of the unions. In most countries freedom of workers to organise themselves into workers unions has never been observed as important by many employers in the textile industries. There is still oppression of the workers union officials and even for the trade union members. Some employers take membership into a union by the worker as a serious sin. In El Salvador, the international Textile Garment and Workers' Federation state that in March 1995, one worker who was active in setting up a trade union in the Gabo S.A enterprise was refused a request to go for medical assistance when she was having serious stomach pains. The lady waited until lunch break to ask for assistance at the local social security 
hospital but very unfortunately she was denied any medical treatment on grounds that her employer had not paid social security contributions or submitted any documentation for her job. That lady finally died that same night. The workers who went for her funeral were, as a result, dismissed (www.globalpolicynetwork.org, 2005).

Still on El Salvador, the textile factory owners were reported to have campaigned to put an end to the trade union. They were campaigning to destroy the Mandarin International Trade Union of Workers and to intimidate the 850 workers, 150 workers belonging to the trade union were dismissed. The company went to the extent of recruiting 24 private security men who threatened and insulted the workers and detained trade unions' officials (Ibid). Assessing job security in textile industries in Lesotho reveals sympathetic findings. From table 1 below, out of 50 workers only 9 are permanent. These casuals are usually laid off or dismissed at any time. A significant number of these labourers out of 50 being 6 have been casual workers for more than 12 months 'normally' with the same employer. This is deliberately done to evade paying workers their due benefits including long service benefits and others, just to maximize profits. They are left in this manner by employers to enable immediate labour cuts and/or dismissals should they go on strike for a living salary. In fact workers do not know how long it takes for them to become permanent. In the short and long-run, foreign but locally credited investors manage to immeasurably maximize profits. There is basically no job security in this sector though it is said to be the fastest growing one.

Table 1: Nature of employment in a textile industry

\begin{tabular}{|c|c|c|}
\hline Employment nature & Frequency & Percentage \\
\hline Casual for 1-3 months. & 17 & 34 \\
\hline Casual for 4-6 months. & 12 & 24 \\
\hline Casual for 7-9 months. & 1 & 2 \\
\hline Casual for $10-12$ months. & 5 & 10 \\
\hline $\begin{array}{l}\text { Casual for more than } 12 \\
\text { months. }\end{array}$ & 6 & 12 \\
\hline Permanent employment. & 9 & 18 \\
\hline Total & 50 & 100 \\
\hline
\end{tabular}

Essentially, at least $82 \%$ of the labourers in this sector are casual and may all turn unemployed right now or tomorrow without any notice, long service benefits or claims. The effectiveness of Lesotho labour law here is naught. The respondents complained that there is no job security because workers become casual workers for a long time, some for even more than a year instead of only three months, a legal probationary period after which one should be confirmed as a permanent employee. Therefore the workers are liable to dismissal at any time when the employer feels like because they would have not signed a contract with the employees. This weakens labour law in Lesotho. The Chinese supervisors are reported to have the tendency of clapping the workers but when the workers fight back, the matter may lead to dismissal or torturing of such a person especially if he $\backslash$ she won the case (Lesotho's Labour Law Effectiveness Interviews, January, 2014).

Unfortunately, the permanent ones, none of them earns above US $\$ 200$ per month. If they have to achieve that they must work beyond six working days and beyond the toiling of 12 hours per day. Normal working hours are eight per day; in this sector the norm is contrary. The permanent are still liable to wage cuts if they become absent on medical or social grounds and can still be dismissed anyhow. If the investor leaves they know that their job is finished and are only permanent as far as the same investor is there. There is actually no future or job security in this sector. Job activities in this textile sector mainly include ironing, machine operating, sewing and cutting, quality controlling, supervising and miscellaneous. The respondents are worried about the long hours they are made to work. However the long and tough working hours, the salaries are unreasonably too low. It is far less than the living wage which is M2, 020.00 ( $M$ = Maloti). Their wages per day range between M27-M35.00 which is M567M750.00 per month (ranging between US\$56 and US\$75 per month) (Lesotho's Labour Law Effectiveness Interviews, January, 2014).

Union membership is very important to workers for job security as collective bargaining is more powerful than individual bargaining. Since trade union is the collective body of workers with similar interests, they become stronger in influencing the decisions taken against them and in negotiating with 
the employers. Labourers were therefore asked whether they are members of any union. There are three main unions found to be operating in the textile industries in Lesotho. They are the Factory Workers Union (FAWU), the Lesotho Clothing and Allied Workers Union (LECAWU), and Lentsoe la Sechaba. Somehow both casual and permanent labourers are members of one of these unions. Most of the members, however, are unable to maintain their yearly subscriptions and this affects availability of union services and results into complacent members/labourers, therefore unions and exploited labourers. Around $40 \%$ of the labourers are not union members and report unions to be helpless and nonprotective. Unions are blamed for not being able to change the too low minimum wage rate (Lesotho's Labour Law Effectiveness Interviews, January, 2014). Bad working conditions within Lesotho textile industries include health, safety and social insecurity. High labour turnover confirming bad working conditions and exploitation. Labourers were asked whether they had worked for any other textile factory besides the one currently working for. Analysis confirms that at least 7 labourers out of 10 have worked in at least two textile factories within 36 months. This is precipitated by prominent dismissible casual labour, unbearable toiling, underpayments and delayed payments, unfair dismissals, imposed and unpaid/underpaid overtimes and too long working hours (Lesotho's Labour Law Effectiveness Interviews, January, 2014).

Workers in textile industries also complain about not being supplied with the nose masks for protection against the strong chemicals that are used in the firms and against dust produced from the cloths for sewing. These masks are supposed to be given on daily basis but they are supplied only when the buyers and inspectors come to check working conditions. One other thing that they are not satisfied with is the absence of the canteens in the firms. No one of these firms has a canteen or the store room for keeping the workers' luggage. They have to leave their lunch boxes and hand-bags in the open space, no matter how is the weather; whether it is rainy, dusty, and sunny or cold, they have to have lunch outside the premises of the factories. Workers know of only two firms that provide double pay for overtimes but nose masks and gloves are not daily given. The embroidery section is reported to be too noisy but workers are never provided with safety equipment against this deafening harmful sound to eardrums. Workers always use cold water for washing and this is a health risk as many of them suffer from cold related ailments (Lesotho's Labour Law Effectiveness Interviews, January, 2014).

One other major problem is when workers have to go for the toilet; they are not allowed to go to toilet when pressed but have to wait for some hours before they can be given permission. That is workers have to be given permission to go to toilet and consequently many usually have digestive problems. Contrary to ILO's conventions, these toilets are normally not in good working condition and are known to be untidy at times with littering human waste. Toilet cleaners are never given gloves to effectively do their job. The respondents also complained that sometimes they go for a day without drinking water and water for flushing toilets. The drinking water is sometimes dirty such that it is red or blue and because there is no alternative they have to drink it (Lesotho's Labour Law Effectiveness Interviews, January, 2014). An already indicated unbearable condition is the way pregnant women are treated. They are expected to produce the same score with the non-pregnant people; this is reported to be very difficult by workers. The pregnant are also given heavy tasks and are made to work standing for the whole day. Apart from that, their maternity leaves are usually not paid; in some cases their contracts were terminated while they were on maternity leave. The fundamental problem here is also that such a document called a contract was never possessed by them to be able to make any liable claims (Lesotho's Labour Law Effectiveness Interviews, January, 2014).

The working hours are also unreasonably long for most firms; 11 hours per day, at least, excluding two 15 minutes breaks and 30 minutes lunch break. Almost every worker interviewed abhorred forced overtimes though some few employers pay it double the normal pay. Generally, leave days are not allowed, everybody is given a payable leave during the December vacation. Production through exploitation for profit maximization seems to be the norm. Many textile factories do not consider workers' leaves necessary; as such they find it unnecessary to pay them as already mentioned. The workers are paid only three days for sick leave even if the days exceed these three days whereas at least 12 legal days have to be paid if one has worked with one employer for continuous six months. Besides that, only medical certificate from certain Doctors are accepted for approval of sick leave while the other ones are regarded as forgeries (Lesotho's Labour Law Effectiveness Interviews, January, 2014).

For many companies, working house temperatures are very extreme because they are too hot in summer and too cold in winter, as already indicated. None of them has temperature control systems, even simple 
ones such as heaters and fans. Factories that have them are found to be inadequately equipped considering their huge space. As a result of these extreme temperatures, the speed of work gets reduced so that workers are hindered from reaching expected target. Many workers have therefore been fired for not reaching the target and the dismissals were not negotiated. Managers also put too much pressure on workers because they get better package when production is higher and this makes them to disregard the prescriptions of the Lesotho Labour Code, imposing overtimes. The respondents said that their major problem is the unreasonably high target they are expected to make every hour, thus every day. Each person is expected to produce 200 items per hour failing which one gets warned and the third warning is replaced by a dismissal without a hearing. Besides being dismissed for being unable to reach the target, the workers are also dismissed for other minor things like talking while working (Lesotho's Labour Law Effectiveness Interviews, January, 2014).

Health and safety committees were established although they do not perform their duties as desired by the Labour Law. They are only active when the Labour Inspectors are coming for inspection and when the buyers are coming to check the working conditions. Furthermore, they are only active when the employers want to pursue their own interests. In one company, CGM, the committee was used when the management wanted to pressurise the workers to sign the contract for policies with the Lesotho Alliance Insurance Company. The workers were not notified $\backslash$ or well informed about these contracts and they were made compulsory for everyone. The committee itself did not even know anything regarding those insurance contracts (Lesotho's Labour Law Effectiveness Interviews, January, 2014). The respondents also complained that there are no sufficient exit doors in the factories though workers are too many. In most cases these doors are kept closed, only one or two doors are used for exit of 400 people in some factories, this causes congestion during the rush hours. The respondents are worried that it can be difficult to escape in cases of emergencies (Lesotho's Labour Law Effectiveness Interviews, January, 2014).

In the mist of all the bad conditions outlined above, only one factory was well spoken of. The respondents said that the working conditions are fair for the reasons that there are trained first aiders who are fully equipped with the first aid kits. One lady proudly said that at her job pregnant women attend the monthly check up at the factory clinic. Furthermore, they are given easier tasks which demand them to sit down, so one can stand voluntarily. Apart from that, they are not expected to have the same score with other workers and they are given time to rest. Other respondents from the same factory said that the salary is reasonable when compared to other companies because they earn M800 per month (equivalent to US $\$ 80$ per month). The whole situation is still meagre and below living standard of at least M2, 020.00 monthly salary. Above all the things that the respondents are impressed with is that the employer takes full responsibility if employees are injured while at work. Only that no worker is satisfied about the minimum wage (Lesotho's Labour Law Effectiveness Interviews, January, 2014).

Interviewees blame the ineffectiveness of labour law on lack of law enforcement, too low minimum wage, poor management practices and general government ignorance. Supervisors or managers in textile factories are reported not to be performing their duties as ought to be in terms of the labour law; personnel officers do not know what they are supposed to do, rather they listen to the top management and take whatever decisions they are told to do regardless of whether it is against the law or not. Moreover, a position/promotion is given to someone not on merit but by biased favours; the employers do not consider the educational background, skills and capabilities when offering a worker some promotion. The personnel offices do only what pleases top management regardless of one's qualifications and experience. Some respondents believe that the government over values investors without concurrently taking into consideration employees' rights and welfare and development of the country as these investors are said to bank their money elsewhere and not in this country. The government is regarded to be too lenient and afraid that if it becomes strict on the investors about the labour laws, this can move investors out of the country. Respondents mainly blame lack of seriousness by government in enforcing labour law (Lesotho's Labour Law Effectiveness Interviews, January, 2014).

\section{Legal Procedures and Effectiveness of Labour Law in Lesotho Textile Sector}


The procedures taken when dealing with workers' problems may give a hint on whether law is being effectively applied. Respondents were asked how they perceive the effectiveness of labour law especially in relation to their problems as the textile industry workers. Almost all of the respondents report Labour Law in Lesotho to be far from being effective because if it were, there would be no complaints and unending several workers' strikes in the textile industries; workers would not be unfairly dismissed; the salaries would at least be the minimum living wage and workers' sick leaves and maternity leaves would be paid. DDPR is also regarded to be working within a poor legal framework of too low minimum wage and too little or no benefits for workers. Apart from unfair dismissals, some people said that after being dismissed, employer just decides not to pay any benefits to the dismissed individual; or the overtime payment due, one respondent said he was paid $125 \%$ instead of $200 \%$ for the overtime, which ought to be double normal pay (Lesotho's Labour Law Effectiveness Interviews, January, 2014).

Apart from the effectiveness of Labour Law, respondents were also asked if they knew the legal procedure they should take when they have job related problems. This is important because it reveals whether workers know their rights and how to solve their work related problems and protect themselves legally if necessary. For the members of the trade unions, a report is given to the shop stewards who will go with such a complainant to the concerned supervisor. Then the shop steward would want to hear from the two parties inclusive of personnel what they are to say and try to reconcile them. If intervention fails, then the case is reported to the next person, the Labour Department. However if the worker is still not satisfied the union sues the employer at DDPR or at the Labour Court. It is important still to note that the way workers deal with their problems differ. Some report to the personnel office and if the personnel cannot help them, they just dismiss the case and quit the job. Others said if they are not satisfied with the decisions of the personnel (in most cases the approval of dismissal) they go and report to the Department of Labour, then the Labour Commissioner or other officials of Labour Department come and intervene. Solutions are expected from the personnel offices, trade unions, DDPR, labour court and labour appeal court. Workers normally have no lawyers due to low income (Lesotho's Labour Law Effectiveness Interviews, January, 2014).

Textile Industry Workers' Opinions Regarding the Lesotho Labour Law Services: Still in the quest for effectiveness of Labour Law towards the textile industry workers, the respondents were asked if they are satisfied with the services they get from the Labour Department. Respondents said they are not satisfied for the reasons that Labour Officers ignore the clients; none of them wants to attend textile industry workers because they are regarded ("baa tena.") to bring too many sickening and tiring cases all the time. At times the cases take too long while workers are still off the job and not getting their monthly wages. Officers are regarded not to be welcoming. Only a few cases are handled properly and timely. DDPR in trying to address this situation speeds up trials/judgements even in the absence of other concerned parties, especially the employer, who at the end had not been properly, timely and sufficiently served with charges and informed of exact dates for hearing. This invites unnecessary legal challenges, long lasting cases and delays. Respondents report the reaction of Law to be very poor and are not satisfied with it. They believe that if it were good, their working conditions would not be as poor as they are. They are always crying that their wages are unreasonably too low compared to the amount of work they do. They report their salary to be even below the living wage in a working condition where they are congested in one place with no heaters and fans; where workers are fired at any time when the employers feel like and where workers fundamental rights are oppressed. Some of these people said they wonder if there is Labour Law in Lesotho because they cannot say how it works and when it is effective. They complain that law lacks enforcement; the cases take too long at the Labour Court and DDPR before judgments. Sometimes they take more than a year until the employer flees or a worker gives up (Lesotho's Labour Law Effectiveness Interviews, January, 2014). The constraints to effective labour law according to textile industry workers include bribing of Labour Officers by employers. One other constraint is valuing of investors by the government at the expense of workers' rights and welfare, treating and making labour to be too cheap in Lesotho. This is due to government fear that strict regulations and reasonable minimum wage will cause investors to flee. Workers also feel that their lower levels of education lead to vulnerability and exploitation, lack of their labour mobility and thus undermining of their rights.

\section{Conclusion}

Textile industry is indeed the fastest growing sector in Lesotho but unfortunately laborers' organizational capacity and effective participation at the floor management level, law or policy formulation level and 
labor law enforcement are naught. Invited investors mostly come from countries villainous of bad labor practices which local exploited labor regard it to be the bad culture of such employers/foreign investors brought down from their countries. Workers even feel that replacing Chinese investors with a different group of investors from developed societies that value labor can result in improved working conditions and effective or truly working labor law. Likewise shareholders are not natives and as such capital flight, lack of multiplier effect, higher GDP than GNP implying lack of 'real' growth except foreign owned one and therefore lack of sustainable development are still characteristic of this sector. Basically this sector promotes underdevelopment as it adds naught to human development and aggravates labor exploitation and cyclic poverty before existing labor laws of Lesotho (Lesotho's Labour Law Effectiveness Interviews, January, 2014).

The government view is that there is excess labor and as thus excess supply classically follows a downward slanting cheap price/salary as affirmed by too low minimum wage rate below the living wage and inflationary impact. This aggravates poverty and work ailments as indicated. This is a hand to mouth occupation for workers. Labor law services are inefficient and scanty as also characterized by too few inspectors for too many factories (Lesotho's Labour Law Effectiveness Interviews, January, 2014). Trade unions have not yet started partaking in inspections and serve as legal assistants of the Labor Commissioner who may if strengthened by such partnership in law enforcement can affect better working conditions. In the context of excess labor there is indefinite casual labor practice of over $50 \%$ of textile industry workers to enable evasion of proper labor welfare-costs, untimely and unfair dismissals, unpaid and/or underpaid imposed overtimes and sick leaves and maternity leaves, delayed payments, mistreatment of expectant women workers by making them do unbearable tasks and scores, unreachable targets enforced by immediate dismissals only for profit maximization ending as capital flight. Congestion, cold water, poor sanitation, slapping of workers by foreign employers, victimization and harassment, toiling beyond normal working hours and so on, also confirm ineffectiveness of labor law in Lesotho.

Sluggish and uncaring labor law services are worsened by government attitude of not wanting to put reasonable living minimum wage and enforce labor laws. Instead foreign investors, some locally credited with capital and offered tax free incentives and infrastructure receive valuable treatment heightened by reported government ignorance to daily labor crisis. Is it an issue of excess labor classically having to be cheap or is it indeed a social fact of undervaluing women's majority labor as usual, ever since and elsewhere? Could it be that ILO's conventions for labor standards, Lesotho labor laws, their servicing and educative role of trade unions have so far been terribly unobserved, ignored and/or underperformed and as thus ineffective by any standards. A strong conviction is that no ruling can allow evil to continue unless it benefits the elite system in one way or another and that without exception trade unions need to know that every form of an administration only responds to pressure (Lesotho's Labour Law Effectiveness Interviews, January, 2014). Bargaining power of trade unions in Lesotho has become toothless due to several constraints already indicated and therefore Lesotho labor law remains good on paper only. In so far as minimum wage rate remains under living wage level, employment creation as well rests a mismatch to poverty alleviation in Lesotho.

Recommendations: Overcoming constraints to labour law effectiveness requires trade unions to become integrated in factories' management structures, educators and skills imparting agents to membership. They need to have power and authority to inspect working conditions and take appropriate legal actions as essential. It is necessary for trade unions to become part of the health and safety committees and strive for maintenance of good working conditions within the industries and not from outside. Shop stewards need to be given more decision making power in facilitating conducive working conditions. It is always necessary to have working committees or boards that have all workers, trade unions, employers and the government represented. Inclusive boards redistribute decision making power relatively more equitably, though such governing boards' members may still be bribed, their finite elected membership positively influences maintenance of proper working conditions and benefits in a better way. Trade unions need to match employers by as well being shareholders in investing so that they may effectively influence and formulate working labour standards for the benefit of employers.

\section{References}

Clean Clothes Campaign. (2001). Report on Textile Industry Workers in Lesotho. Maseru: GoL Damachi, U. (1979). Industrial relations in Africa. London: Macmillan Press. 
Hugh, A. C. (1985).The History of British Trade Unions Since1889.vol 11. Oxford: Claeidon Press.

Hyman, N. (1987). Industrial Relations: A Marxist Introduction. London: Macmillan.

Interviews conducted on Lesotho's Labour Law Effectiveness (January, 2014). "The Critical Exposure of Lesotho's Labor Law Effectiveness: Industrial Relations' Calamity of Textile Industry Workers in Lesotho".

Kahn-Freund, O. (1972). The Labor and the Law. London: Stevens \& Sons Limited.

Lesotho Labor Code (Amendment) 2000-25 th April, (2000). Maseru: GoL.

Lesotho Government Gazette Extra Ordinary. Vol xxx1x.5 th April 1994.No 30.

Lesotho National Development Corporation/LNDC-Investors Guide (14 July 2013), Producing Garments in Lesotho. Maseru: GoL.

Panford, K. (1994). African Labor Relations and Workers' Rights: Assessing the Role of ILO. London; Green Wood Press.

Sako, M. \& Sato, H. (1997). Japanese Labor and Management in Transition: Flexibility and Participation. Routledge: London.

Tikriti, A. (1982). Tripartism and ILO. Uppsala: Uppsala University Press.

www.ilo.org. (2005). Accessed on $6^{\text {th }}$ January, 2014.

www.icftu.org, 2005. Accessed on $6^{\text {th }}$ January, 2014.

www.factmonster.com, 2013. Accessed on $6^{\text {th }}$ January, 2014.

www.globalpolicynetwork.org, 2005. Accessed on $6^{\text {th }}$ January, 2014.

Www.wsws.org. World Socialist Website. (2013). Accessed on 27 October, 2013. 